\title{
Customer Services and Technology Used in Financial Institutions: A Survey Research
}

\author{
Yvar Geerman, Suhansa Rodchua* \\ School of Technology, University of Central Missouri, USA
}

Copyright $\bigcirc 2016$ by authors, all rights reserved. Authors agree that this article remains permanently open access under the terms of the Creative Commons Attribution License 4.0 International License

\begin{abstract}
Customer services and technology used in today's business are subjected to continuous improvement in a pursuit to enhance work performance and customer satisfaction. The purpose of this study is to determine the most important dimension of customer satisfaction perceived by three different groups of participants in financial institutions: college students, employees, and retired individuals. The study used online questionnaire in data collection with 126 respondents from the University of Central Missouri community. The results indicated that reliability was the most important dimension of customer satisfaction. Other important dimensions were responsiveness, security, and credibility. One-way Analysis of Variance and SPSS 21.0 was utilized as a statistical tool to determine the relationship among variables. With alpha 0.05 level, the hypotheses testing showed that there was no significant difference in the most important dimension of customer satisfaction between genders and between different groups of participants. This study recommended that the research in customer satisfaction and technology used in financial institutions must be on-going process with emphasis on long-term relationship with their customers.
\end{abstract}

Keywords Customer Satisfaction, Financial Services, Technology Used, Service Dimension

\section{Introduction}

Customer service is an important element not only for the manufactory industry, but also for the service industry. Like any other enterprises, financial institutions need their customers in order to stay in business. An organization can bring a customer to the firm, but to retain the client is the most delicate job for any kind of business. In a study made by J.D Power and Associates "9.6 percent of customers in 2012 indicate they switched their primary banking institution during the past year to a new provider. This is up from 8.7 percent in 2011 and 7.7 percent in 2010" [1] (para3). In the recent years more and more financial institutions have started to take closer attention to their customer services.

The financial institutions want to portray superiority to their competitors so the customers can see they have the best product and price, but most importantly, the best customer service in the industry. The Center for the Advancement of Process Technology defines quality as "the performance, products, and services that consistently meet or exceed the expectations of the customer by doing the right job, the right way, the first, every time" [2] (p268). A financial institution needs to meet or even exceed the expectations of their customer. They only have one time to impress their clients with their products or services they offer.

To focus on the quality of services, a number of researchers and studies started creating instruments that can help them understand customer satisfaction better. Parasuraman, Zeithaml, and Berry created the tool in the mid-1980s; it is called the SERVQUAL scale in order to measure quality in the service industry. They believed that customer satisfaction is dependent on ten dimensions of service quality which are: tangibles, reliability, responsiveness, competence, courtesy, credibility, security, access, communication, and empathy [3].

\section{Statement of the Problem and the Purpose}

Technology can affect the quality of service the bank is trying to offer. Nowadays there are many innovative and convenient services that did not exist years ago, such as like mobile banking and online banking. Even though all of these services are extremely helpful in giving customers flexibility of when they would like to use the bank services, it can actually hurt the quality of service. Technology cannot be $100 \%$ trusted to be reliable and effective; for example, the mobile banking application using a phone connection can crash. The customers need to keep updating certain computer applications in order to use the service or even customers need to have a certain electronic device in order to use a service. In a statement made by Eisingerich and Bell (2006) "because of clients inability to evaluate technical service outcomes can bias or obstruct service quality perception and affect their degree of confidence in a firm" [4] (p88). All of 
this can lead the customers to not enjoy the quality of service they were expected to receive. Another aspect about technology is that it can be time consuming for the clients. Banks try to offer a great variety of new services, but a lot of times customers need to answer several security questions before being able to use the product. On many occasions there are no manual or workshop on how to use a certain product. Consequently customers will spend hours trying to figure out how to do certain transaction, or finding out all the possible services that can be accessed online without traveling to a branch office.

The purpose of this study was to determine the most important customer service dimensions of financial institutions perceived by three groups of customers: college students, employees, and retired individuals. The study also reported the level of satisfaction of customers services received by financial institutions depend on how often they go to their financial institutions. This study's finding should be helpful for finance officers:

- to compare and contrast their philosophies about which dimensions of customer service are important,

- to focus on the affects the group(s) of customers they are trying to attract and,

- to improve their own customer service.

The study was also intended to help post-secondary education institutions with information that can be presented to students to help them understand better customer's opinions about customer service in financial institutions.

\section{Research Questions}

1. Is there a difference in the most important dimension of customer satisfaction between college students, employees, and retired individuals?

2. Is there a difference in the most important dimension of customer satisfaction between male and female customers?

3. Is there a difference between the gender of the customers and which method they prefer to get assisted by their financial institutions?

4. Does the level of satisfaction of customers' services received by financial institutions depend on how often they go to their financial institutions?

\section{Research Hypotheses}

$\mathrm{H}_{1:}$ There is no significant difference in the most important dimension of customer satisfaction between college students, employees, and retired individuals.

$\mathrm{H}_{2:}$ There is no significant difference in the most important dimension of customer satisfaction between male and female customers.

$\mathrm{H}_{3}$ : There is no significant difference between the gender of the customers and which method they prefer to get assisted by their financial institutions.

$\mathrm{H}_{4}$ : There is no significant difference on how often the customers go to the bank and their level of satisfaction.

\section{Review of Literature}

Financial institutions are seen as very important in the eyes of the customers, because customers trust them with their money. If a customer does not like the product or service they are receiving there is a good chance that customers will change institutions. Lucas argued that financial institutions need "to remember in serving others is that today's consumers are far more educated and informed than any point in history. They are also more selective, have more choices, and are more demanding than their predecessors" [5] (p33). For that same reason financial institutions need to strive to offer their customers the best service possible. In a statement made by Lopez Alarcon "Customer satisfaction is an important factor to the success of businesses. One of the aspects that will make a customer choose certain products or companies over others will be the level of customer satisfaction and support before and after the sales \& services provided" [6] (p18). Customers are highly important to the financial institutions but also any kind of business because without customers they would not be able to stay in business.

Customer satisfaction is highly important to any kind of businesses, including financial institutions. It is for that reason that many researchers started creating instruments that can help them understand customer satisfaction better. Parasuraman, Zeihaml, and Berry created in the mid-1980's the SERVQUAL scale to measure the service quality in the service industry [3]. According to Buttle, SERVQUAL "is conceptualized as a gap between what the customer expects by way of service quality from a class of service provider and their evaluations of the performance of a particular service provider" [7] (p9). In the original SERVQUAL, the researchers believed that that customer satisfaction is dependent on ten dimensions of service quality. The ten dimensions of customer satisfaction that were discussed in the article are tangibles, reliability, responsiveness, competence, courtesy, credibility, security, access, communication, and empathy. All of these dimensions are considered important in the opinion of the consumers that business needs to keep in mind.

\section{Methodology}

The population of this research were students, employees, and retired individuals who were 18 years or older, from University of Central Missouri located in Warrensburg, Missouri (US) and have a bank account. All of these participants use banks for different reasons. The population of this research was invited by email and social media to participate in this research. The online questionnaire was approved by the Human Subject Committee at the university level. This questionnaire instrument was created using GoogleDoc and posted for 5 weeks in December 2012, see Appendix A. Statistical Analysis of this research included the help of Microsoft Excel and SPSS version 21.0. To test 
all four hypotheses, the researcher used one-way Analysis of Variance (ANOVA) with alpha at the level of 0.05 statistical significance.

\section{Findings and Data Analysis}

The results indicated a total of 126 respondents completing the questionnaire. The findings are grouped into three major parts: 1) Demographic and descriptive information of the respondents, 2) Ten dimensions of customer satisfaction, and 3) Data analysis and hypothesis testing

\section{Part One: Demographics and Descriptive Information of the Respondents}

There were a total of six survey questions related to the demographics of the respondents, as follows: the gender of the respondents, the age of the respondents, the occupation of the respondents, the method of transaction that the respondent use more often, how often the respondent goes to their bank and how satisfied are the customer with the services provided by their financial institution. Table 1 presents a summary of respondents' demographic data.

Table 1. A summary of Respondents' demographic data

\begin{tabular}{|c|c|c|c|}
\hline \multicolumn{2}{|c|}{ Respondents' data } & \multirow{2}{*}{$\begin{array}{c}\text { Frequency } \\
30\end{array}$} & \multirow{2}{*}{$\begin{array}{c}\begin{array}{c}\text { Percent } \\
(\%)\end{array} \\
23.8\end{array}$} \\
\hline Age & $18-28$ years & & \\
\hline & $29-39$ & 12 & 9.5 \\
\hline & $40-50$ & 20 & 15.9 \\
\hline & 51 or older & 64 & 50.8 \\
\hline \multirow[t]{3}{*}{ Occupation } & College Student & 39 & 31 \\
\hline & Retired Individual & 37 & 29.4 \\
\hline & Employee & 50 & 39.7 \\
\hline \multirow[t]{2}{*}{ Gender } & Female & 65 & 51.6 \\
\hline & Male & 61 & 48.4 \\
\hline \multirow{5}{*}{$\begin{array}{c}\text { Method } \\
\text { often used }\end{array}$} & Online Banking & 66 & 52.4 \\
\hline & Go inside a branch & 26 & 20.6 \\
\hline & Telephone Banking & 2 & 1.6 \\
\hline & Drive-thru & 13 & 10.3 \\
\hline & ATM & 17 & 13.5 \\
\hline How often & $\begin{array}{c}\text { Less than } 2 \text { times a } \\
\text { month }\end{array}$ & 63 & 50 \\
\hline \multirow[t]{2}{*}{ go to the bank } & $\begin{array}{c}\text { Not be inside past } 6 \\
\text { months }\end{array}$ & 23 & 18.3 \\
\hline & $\begin{array}{c}\text { More than } 2 \text { times a } \\
\text { month }\end{array}$ & 40 & 31.7 \\
\hline \multirow{3}{*}{$\begin{array}{c}\text { Satisfaction } \\
\text { with the } \\
\text { services }\end{array}$} & not satisfied & 3 & 2.4 \\
\hline & neutral & 25 & 19.8 \\
\hline & very satisfied & 98 & 77.8 \\
\hline
\end{tabular}

- Respondents' age - the useable responses include 30 $(23.8 \%)$ in the $18-28$ age group, $12(9.5 \%)$ in the $29-39$ age group, $20(15.9 \%)$ in the $40-50$ age group, and 64 $(50.8 \%)$ in the 51 or older age group.

- Respondents' occupation - The usable responses include $39(31 \%)$ as college students, $37(29.4 \%)$ as retired individual, and $50(39.7 \%)$ as employees.

- Respondents' gender - The usable responses include 65 $(51.6 \%)$ identified themselves as female and $61(48.4 \%)$ identified as male.

- Method they used more often to do a transaction. The usable response includes $66(52.4 \%)$ as online banking, $28(20.6 \%)$ as go inside a branch, $2(1.6 \%)$ as telephone banking, $13(10.3 \%)$ as drive-thru of your financial institution, $17(13.5 \%)$ as ATM, and $2(1.6 \%)$ as mobile banking.

- How often respondents go to their bank. The usable response includes $63(50 \%)$ as fewer than 2 times per month, $23(18.3 \%)$ as I have not stepped inside a bank in the past 6 months, and $40(31.7 \%)$ as 2 times or more per month.

- How satisfied they were with the services provided by their current financial institution(s). The usable responses included $3(2.40 \%)$ as not satisfied, 25 $(19.8 \%)$ as neither satisfied nor not satisfied', and 98 $(77.8 \%)$ as very satisfied.

\section{Part Two: Ten Dimension of Customer Satisfaction}

In this section of the questionnaire, respondents were asked to rank each subcategory within each category. The 10 dimensions of customer satisfaction were listed, and each category had subcategories for the students, employees and retired individuals to rate. For example, category one is tangible. This category was listed in four subcategories: appearance of physical facilities, appearance of equipment, appearance of personnel, and appearance of communication materials. The students, employees and retired individuals were asked to rank each category. The scale was from 1 to 5 as; $1=$ not important, $2=$ less important, $3=$ neutral, $4=$ somewhat important, and $5=$ very important. When the data was collected, the researcher calculated the mean for each dimension of customer satisfaction.

The female respondents scored reliability as the most important dimension of customer satisfaction with a mean of 4.95. The male respondents scored reliability also as the most important dimension of customer satisfaction with a mean score of 4.96. Based on occupation, college students scored both reliability and responsiveness the same as the two most important dimensions of customer satisfaction with a mean score of 4.92. The Retired Individual scored competence as the most important customer satisfaction with a mean score of 4.99. The employees scored reliability as the most important dimension of customer satisfaction with a mean score of 4.95. Based on the overall opinion of respondent's perception, the most important customer satisfaction is reliability with a mean score of 4.95 . Table 2 shows the calculated average of each service dimension based on respondents' gender, occupation, and overall. 
Table 2. The means of each service dimension based on gender and occupation

\begin{tabular}{ccccccc}
\hline \multicolumn{2}{c}{ Gender } & & Occupation & & Overall \\
\hline & Female & Male & $\begin{array}{c}\text { College } \\
\text { Students }\end{array}$ & $\begin{array}{c}\text { Retired } \\
\text { Individuals }\end{array}$ & Employee & Average \\
Tangibles & 4.00 & 3.86 & 4.10 & 4.00 & 3.93 & $\mathbf{3 . 9 3}$ \\
Reliability & 4.95 & 4.96 & 4.92 & 4.95 & 4.95 & $\mathbf{4 . 9 5}$ \\
Responsiveness & 4.88 & 4.89 & 4.92 & 4.88 & 4.88 & $\mathbf{4 . 8 8}$ \\
Competence & 4.86 & 4.95 & 4.82 & 4.99 & 3.93 & $\mathbf{4 . 9 0}$ \\
Courtesy & 4.77 & 4.66 & 4.79 & 4.66 & 4.72 & $\mathbf{4 . 7 2}$ \\
Credibility & 4.83 & 4.91 & 4.83 & 4.95 & 4.87 & $\mathbf{4 . 8 7}$ \\
Security & 4.78 & 4.85 & 4.87 & 4.91 & 4.86 & $\mathbf{4 . 8 6}$ \\
Access & 4.05 & 3.99 & 4.21 & 3.85 & 4.02 & $\mathbf{4 . 0 2}$ \\
Communication & 4.52 & 4.63 & 4.58 & 4.66 & 4.58 & $\mathbf{4 . 5 8}$ \\
Empathy & 4.28 & 4.35 & 4.26 & 4.49 & 4.49 & $\mathbf{4 . 3 1}$
\end{tabular}

\section{Part Three: Data Analysis and Hypotheses Testing}

The computation of the one-way ANOVA was performed to test 4 research hypotheses; alpha 0.05 or $95 \%$ confidence level was utilized in this study. Table 3 presents the $\mathrm{F}$ statistic and observed significance values of the four research hypotheses.

Table 3. Research Hypotheses Testing

\begin{tabular}{llll}
\hline Hypotheses & Variables & F & Sig. \\
\hline H1 & dimension * occupation & 0.798 & 0.453 \\
H2 & dimension * gender & 0.006 & 0.937 \\
H3 & gender * method often used & 1.858 & 0.175 \\
H4 & $\begin{array}{l}\text { how often go to bank * } \\
\text { satisfaction }\end{array}$ & 2.956 & 0.056 \\
Analysis of Variance, alpha $=0.05$ & & \\
\hline
\end{tabular}

Reliability was used in this ANOVA calculation because the overall respondents rated this dimension as the most important dimension of customer satisfaction. The results and interpretation of hypotheses testing are explained:

- Hypothesis One: The F statistic is 0.798 and the observed significance level is 0.453 , so the null hypothesis is not rejected, and the alternative of a difference is not tenable. In other words, there is no significant difference in the most important dimension of customer satisfaction between college students, full time employee, and retired individuals.

- Hypothesis Two: The F statistic is 0.006 and the observed significance level is 0.937 , so the null hypothesis is not rejected. There is no significant difference in the most important dimension of customer satisfaction between male and female customers.

- Hypothesis Three: The F value is 1.858 and the observed significance level is 0.175 , so the null hypothesis is not rejected. There is no significant difference between the genders of the customers on which method they prefer when getting assisted by their financial institutions.

- Hypothesis Four: The F statistic is 2.958. The observed significance level is 0.056 , so the null hypothesis is not rejected, and the alternate is not tenable. In other words, there is no significant difference between how often the customers go to the bank and their level of satisfaction with services provided.

\section{Discussion and Conclusions}

Figure 1 displays the most important dimension based on the occupation of the respondents. Based on occupation, the top five dimensions of customer satisfaction for college students are reliability, responsiveness, security, credibility, competence, and courtesy. The college students rated both reliability and responsiveness as equally important dimensions of customer satisfaction with a mean score of 4.92. The top five dimensions of customer satisfaction of retired individuals are competence, reliability, credibility, security and responsiveness. The retired individual rated competence as the most important dimension of customer satisfaction with a mean score of 4.99. The top five dimensions of customer satisfaction for the employees are reliability, responsiveness, credibility, security, and courtesy. The employee rated reliability as the most important dimension of customer satisfaction with a mean score of 4.95 .

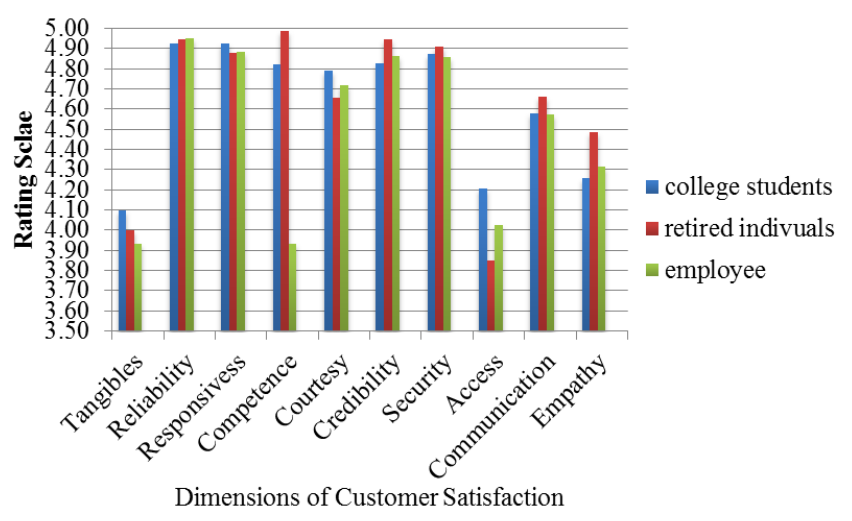

Figure 1. Most important Dimension of Customer Satisfaction based on Occupation

Figure 2 displays the most important dimension based on 
the age of the respondents. Based on age, the top 5 dimensions of the customer satisfaction for the age group of 18-28 are: reliability, responsiveness, security, courtesy, and credibility. The 18-28 age group rated reliability as the most dimension of customer satisfaction with a mean score of 4.90 . The top five dimensions of the customer satisfaction for the age group of 29-39 are: reliability, competence, credibility, responsiveness, security, and courtesy. The 29-39 age group rated both reliability and competence as equally important dimensions of customer satisfaction with a mean score of 5.00. The top five dimensions of customer satisfaction for the age group of 40-50 are: responsiveness, competence, reliability, credibility, security, and courtesy. The 40-50 age group rated both responsiveness and competence as equally important dimensions of customer satisfaction with a mean score of 4.98. The top five dimensions of the customer satisfaction for the age group of 51 or older are reliability, competence, credibility, security, and responsiveness. The 51 and older age group rated reliability as the most important dimension of customer satisfaction with a mean score of 4.97 .

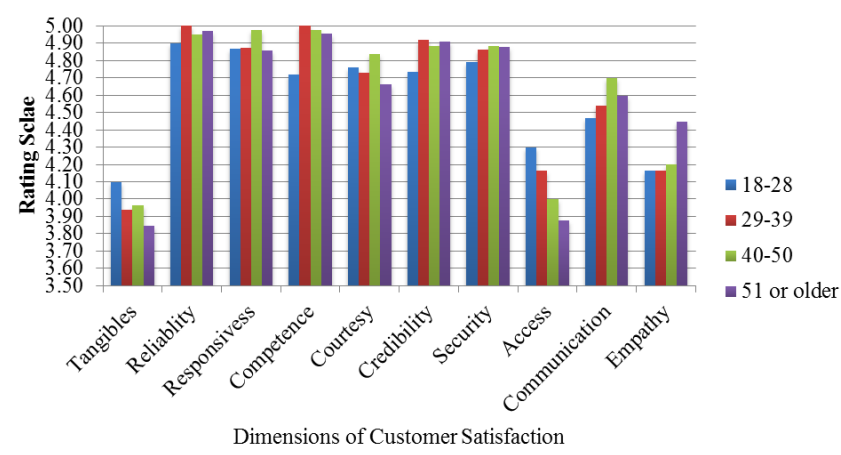

Figure 2. Most important Dimension of Customer Satisfaction based on Age

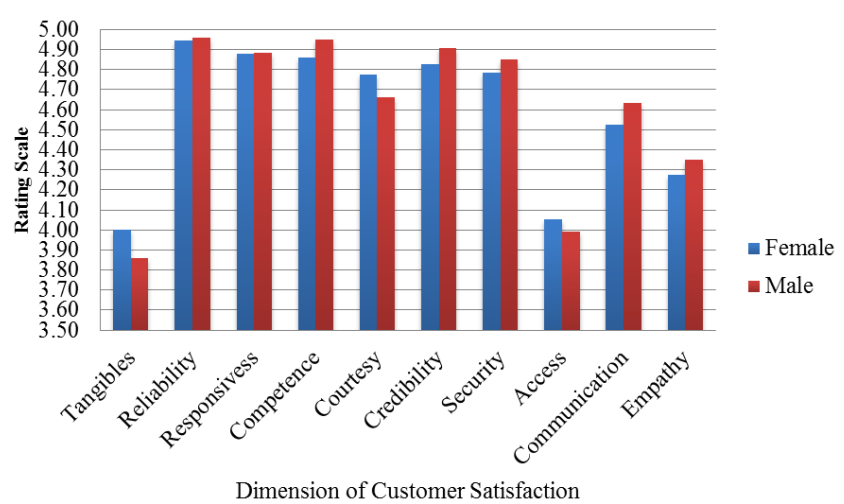

Figure 3. Most important Dimension of Customer Satisfaction based on Gender

Figure 3 displays the most important dimension based on the gender of the respondents. Based on gender, the top 5 dimensions of customer satisfaction for the female respondents are: reliability, responsiveness, competence, credibility, and security. The female respondents rated reliability as the most important dimensions of customer satisfaction with a mean score of 4.95. The top five dimensions of customer satisfaction for the male respondents are: reliability, competence, credibility, responsiveness, and security. The male respondents rated reliability as the most important dimensions of customer satisfaction with a mean score of 4.96.

Based on this research, the researcher can conclude that reliability is the most important dimension of customer satisfaction. Based on Figure 3, reliability was ranked as the most important customer satisfaction in the overall all respondents, with a mean score of 4.95 out of 5 . The college students, employees, and retired individuals all agreed that besides reliability, there also need to be responsiveness, security, and credibility for them to enjoy the service.

The 18-28 age group, 29-39 age group, 40-50 age group, and 51 or older age group all agreed that besides reliability, there also needs to be responsiveness, security, and credibility for them to enjoy the service.

The female and male gender both agreed that besides reliability, responsiveness, security, credibility, and competence are also important in order for them to enjoy the service.

Customer perspective on being happy with the services provided by their financial institution, they need to know that their financial institutions will be able to perform the promised service not only dependably but also accurately. Customers need to be assured that their financial institution is willing to help them with prompt service. One way that financial institutions can improve their services is to make sure that their customers have a freedom from danger, risk or doubt with the services provided by them. More and more customers use the online banking services. Technology used in network security must be effective keeping information more secure and the system running smoothly. There are layers of network security that can be monitored, including ethical standpoint to simple training methods and implementation of a firewall and antivirus programs.

In addition, the authors recommend that this subject be further studied in more specific detail. The study finding is highly interesting and important to present not only to education, but also to business sections. The further study could focus on the replication of this research with different types of industries (e.g. healthcare, telecommunication, retail,.). This information can be compared and contrasted to see if customers from different industry think the same as the ones of the financial industry

Like any other business, financial institutions need their customers in order to survive and make profits; this is a reason why research in customer satisfaction needs to be continuous improvement process. An organization can bring a customer to the firm, but to retain the client is the most delicate job for any kind of business. The customers should feel that they can always rely on the trustworthiness, believability, and honesty of the financial institution. If a company is able to have a superior customer satisfaction and can create long-term relationships with their customers, they can be highly successful in their operations. 


\section{Appendix A}

\section{Questionnaire}

The researcher would like to thank you for filling in this questionnaire. You responses are extremely important. Please be aware that the responses you give will be kept confidential and will be used for research purposes only. If you have any questions, please do not hesitate in contacting the researcher at: xxxxx@xxxxx, or by phone: (xxx)-xxx-xxxx. If you have any questions about your rights as a research participant, please contact the Human Subjects Protection Program at (xxx)-Xxx-Xxxx. Please choose answer for all the questions on this page, when you are done click on "submit".

\section{Disclaimer}

Please be aware that this study is completely voluntary, that there will be no compensation and that your individual answers will be held in the strictest confidence and in no way will be traceable to you.

\section{- I agree}

\section{Section 1: Your Opinion about Customer Service}

Please answer the following questions based on what you think is important in order to enjoy the services of your current financial institution(s). The options are not important, less important, neutral, somewhat important, and very important. Check on your selected answer.

\begin{tabular}{|c|c|c|c|c|c|}
\hline & $\begin{array}{c}\text { Not } \\
\text { important }\end{array}$ & $\begin{array}{c}\text { Less } \\
\text { important }\end{array}$ & Neutral & $\begin{array}{c}\text { Somewhat } \\
\text { important }\end{array}$ & $\begin{array}{c}\text { Very } \\
\text { important }\end{array}$ \\
\hline \multicolumn{6}{|c|}{$\begin{array}{l}\text { Block 1: Tangibles } \\
\text { Appearance of physical facilities, equipment, personnel and communicating material. }\end{array}$} \\
\hline \multicolumn{6}{|l|}{\begin{tabular}{|c|c|} 
Appearance of physical facilities & \\
\end{tabular}} \\
\hline \multicolumn{6}{|l|}{ Appearance of equipment } \\
\hline \multicolumn{6}{|l|}{ Appearance of personnel } \\
\hline \multicolumn{6}{|l|}{ Appearance of communication material } \\
\hline \multicolumn{6}{|c|}{$\begin{array}{l}\text { Block 2: Reliability } \\
\text { Ability to perform the promised service dependably and promised service accurately. }\end{array}$} \\
\hline \multicolumn{6}{|c|}{\begin{tabular}{|l|l|} 
Ability to perform the promised service dependably & \\
\end{tabular}} \\
\hline \multicolumn{6}{|l|}{ Ability to perform the promised service } \\
\hline \multicolumn{6}{|l|}{$\begin{array}{l}\text { Block 3: Responsiveness } \\
\text { Willingness to help customers and provide prompt service }\end{array}$} \\
\hline \multicolumn{6}{|l|}{ Willingness to help customers promptly } \\
\hline \multicolumn{6}{|l|}{ Ability to provide prompt service } \\
\hline \multicolumn{6}{|l|}{$\begin{array}{l}\text { Block 4: Competence } \\
\text { Possession of the required skills and knowledge to perform the service }\end{array}$} \\
\hline \multicolumn{6}{|l|}{ Having the required skills to serve clients } \\
\hline \multicolumn{6}{|l|}{ Service personnel having the knowledge necessary to perform their duties } \\
\hline \multicolumn{6}{|l|}{$\begin{array}{l}\text { Block 5: Courtesy } \\
\text { Politeness, respect consideration and friendliness of contact personnel }\end{array}$} \\
\hline \multicolumn{6}{|l|}{ Politeness of the service personnel } \\
\hline \multicolumn{6}{|l|}{ Respect toward the customer by the personnel } \\
\hline \multicolumn{6}{|l|}{ Consideration of the customer's needs by the personnel } \\
\hline \multicolumn{6}{|l|}{ Friendliness of contact personnel } \\
\hline \multicolumn{6}{|l|}{$\begin{array}{l}\text { Block 6: Credibility } \\
\text { Trustworthiness, believability and honesty of the service provider }\end{array}$} \\
\hline \multicolumn{6}{|l|}{ Trustworthy of the company and employees } \\
\hline \multicolumn{6}{|l|}{ Believability of the personnel } \\
\hline \multicolumn{6}{|l|}{ Honesty of the service provider } \\
\hline \multicolumn{6}{|l|}{$\begin{array}{l}\text { Block 7: Safety } \\
\text { Freedom from danger, risk or doubt }\end{array}$} \\
\hline \multicolumn{6}{|l|}{ Safety of the clients' funds } \\
\hline \multicolumn{6}{|l|}{ Trust in the institution's ability to manage the clients finances effectively } \\
\hline Ability of the institution to convey personal trust & & & & & \\
\hline
\end{tabular}




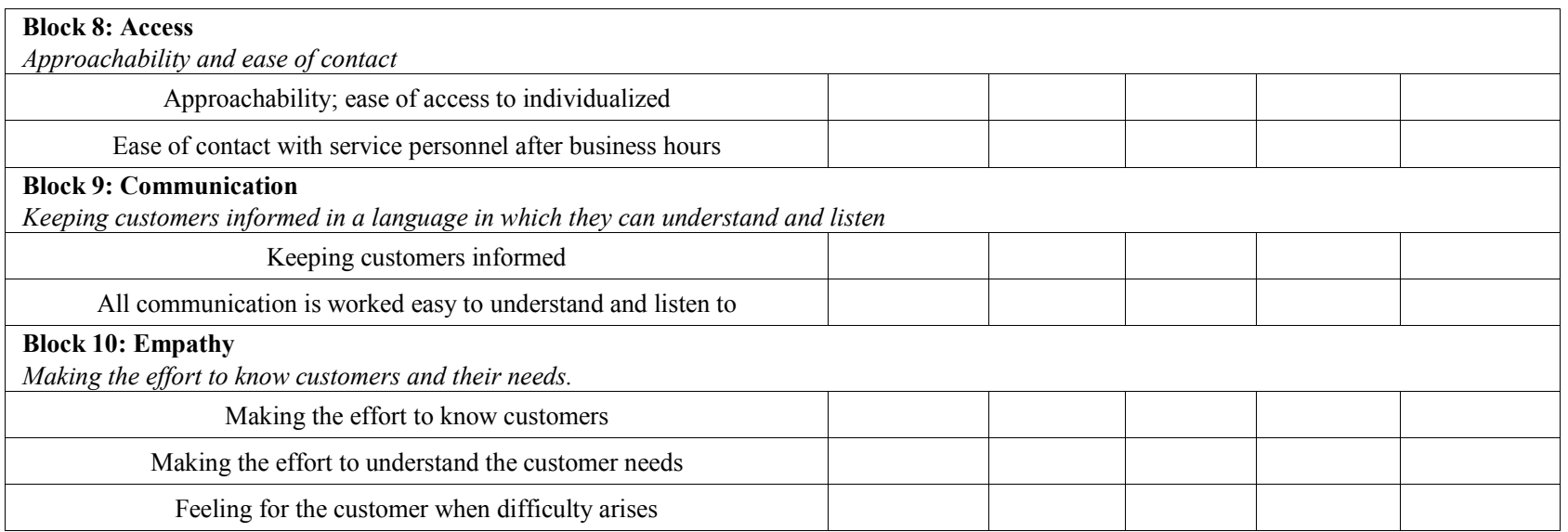

\section{Section 2: Demographics Information}

- Gender:

- Male

- Female

- Age:

- $18-28$

- 29-39

- 40-50

- 51 or older

- On the UCM campus I am considered a(n)

- College Student

- Employee

- Retired Individual

- In the past 6 months, if you needed to do a transaction from your bank account, which method did you use more often?

- Online banking

- Go inside a branch

- Telephone Banking

- Drive-thru of your financial institution

- ATM

- Mobile Banking (for example, Apps, Text)

- How often do you go to your bank?

- Less than 2 times per month

- I have not stepped inside a bank in the past 6 months

- More than 2 or more per month.

- How satisfied are you with the services provided by your current financial institution(s)?

- Not very satisfied

- Not satisfied

- Neutral

- Satisfied

- Very satisfied
Note: this questionnaire was created and adapted the service dimensions from the studies of Parasuraman, Zeithaml, \& Berry [3] and López-Alarcón [6]

$* * * * * * * * * * * * * * * * * * * * * * * * * * * * * * *$

Your response has been recorded. I really appreciate your answers and the time you took to fill in this questionnaire

\section{REFERENCES}

[1] J.D. Power \& Associates. (2012, February ). J.D Power \& Associates. Retrieved from http://businesscenter.jdpower.com/news/pressrelease.aspx?I $\mathrm{D}=2012017$

[2] Center Advancement of Process Technology. (2011). Process quality. Upper Saddle for the River, NJ: Prentice Hall.

[3] Parasuraman, A., Zeithaml, V.A., \& Berry, L.L. (1988). SERVQUAL: A multiple item scale for measuring perceptions of service quality. Journal of Retailing, 64(1), $12-40$.

[4] Eisingerich, A. B., \& Bell, S.J. (2006). Relationship marketing in the financial services industry: The importance of customer education, participation and problem management for customer loyalty. Journal of Financial Services Marketing, 10(4), 86-97.

[5] Lucas, R. W. (2011). Please every customer: Delivering stellar customer service across cultures. New York: McGraw Hill.

[6] Lopez Alarcon, J. S. (2003). The Dimensions of Customer Satisfaction In the Financial Services Industry. Boca Raton, FL: Lynn University.

[7] Buttle, F. (1996). SERVQUAL: Review, Critque, research agenda. European Journal of Marketing, 30 (1). 